\title{
EXPERIMENTAL ELECTROCHEMICAL REMOVAL OF COPPER SPLINTERS FROM THE ISOLATED VITREOUS*
}

\author{
BY \\ T. KRWAWICZ AND K. ZAGÓRSKI \\ From the Ophthalmological Clinic, Medical Academy, Lublin, Poland
}

THE penetration of a splinter of copper or copper alloy into the eye always presents a serious problem. If the metal, especially in a relatively pure state, is left in the eye, it is bound to produce a heavy reaction in the form of acute iridocyclitis, violent uveitis, or vitreous abscess with all the sequelae of these conditions. Copper alloys containing less than 85 per cent. of copper usually cause a less severe reaction, but then chalcosis may develop, a condition which in most cases leads to a gradual loss of vision, although its course depends on the individual tolerance of the eye to the metal.

The most reasonable though not the easiest course of action is to remove the copper splinter mechanically, using one of the methods devised for the removal of non-magnetic foreign bodies. These methods, though constantly being improved, are still far from perfect. Both the older instruments, such as the Desmarres-Luer forceps, and the more recent ones, such as the Holth forceps or the endoscopic appliances, may prove inadequate, and the only result of the operation will be a severe additional trauma. The risk is sometimes so grave that all idea of operative treatment must be abandoned.

Some investigators have endeavoured to coat the splinter with a deposit of a neutral metal, such as gold, or to produce a magnetic alloy with iron (DukeElder, 1954). Müller (1931) and Habig, Lumen, and Snacken (1951) tried to convert copper into a harmless compound by the local or general application of sodium thiosulphate or sodium hyposulphite. Such attempts, as well as those making use of the property of BAL to form an insoluble compound with copper (Newell, Cooper, and Farmer, 1949), have been failures from the clinical point of view. The idea of introducing in the region of the foreign body an amalgam to which the latter would then attach itself firmly enough to be withdrawn (Wölflina, 1946) was no more successful than that of removing a non-magnetic foreign body by means of electro-magnetic forces (Endt and Ten Doesschate, 1949).

Nevertheless, the idea of a non-instrumental method of removing a copper foreign body from the eye is so attractive that it should not be given up before all possibilities have been investigated.

The purpose of our experiments was to examine the possibility of the

$$
\text { * Received for publication April 23, } 1957 .
$$


electrochemical removal of copper from the isolated vitreous. In this connexion two questions had to be answered:

(1) Is it possible to dissolve a small copper splinter electrolytically, using the vitreous as electrolyte, and what is the efficiency of this process in experimental conditions?

(2) To what extent is it possible to deposit the previously dissolved metal on the cathode, and what is the efficiency of this process?

\section{Methods}

A concavity ground in a glass plate was filled with fresh bovine vitreous. The capacity of the concavity was about $6 \mathrm{ml}$. In the vitreous, which was to play the part of an electrolyte, copper splinters were placed, their weight ranging from 1.6 to $5.4 \mathrm{mg}$., and their diameter from 2 to $3 \mathrm{~mm}$. Then the active electrode (anode) was so placed in the vitreous that it came into contact with the copper splinter. Near the edge of the vessel, 15 to $20 \mathrm{~mm}$. away from the splinter, a subsidiary electrode was immersed in the vitreous. A platinum needle was used as the working electrode; in some of our experiments this was coated with an insulating material, only a point $0.5 \mathrm{~mm}$. long being left bare. When the direction of the electric current was to be changed, this electrode was replaced by a non-insulated platinum needle. As the subsidiary electrode, a platinum plate was used, measuring $2 \times 5 \mathrm{~mm}$., and mounted in glass. The current was supplied by a small dry battery with branches from the separate cells so that a tension of $1.5,3.0$, or $4.5 \mathrm{~V}$ could be chosen. The intensity of the current was measured with a milliampèremeter, the sensitivity of which was $7 \mathrm{~mm}$./ $1 \mathrm{~mA}$. To facilitate the manipulation of the electrodes, a special stand was built with movable clamps for the electrodes and a magnifying glass as an aid in observing the electrolytic process.

After the electrodes had been placed in position, the electric circuit was closed. If the contact between the anode and the copper splinter was maintained, the needle of the galvanometer moved from its initial position. At the same time hydrogen bubbles began to appear round the subsidiary electrode, and a few seconds later a greenish stain could be seen in the vitreous round the anode, which pointed to a gradual dissolution of the copper. The time and the galvanometer readings were taken. When the current intensity began to fall and when it was found that this was due to the complete dissolution of the copper, the time and the final current intensity were again taken, and then the direction of the current was reversed, the working electrode becoming the cathode and vice versa. The immediate effect of this, as observed on the galvanometer, was an abrupt rise in the current intensity, which was ten times higher than that of the dissolving current. At that moment the copper which had been dissolved in the vitreous began rapid deposition on the platinum needle (cathode). The time and current intensity were recorded and, when the latter fell to a constant level, a quantity of 
current two or three times higher than the theoretical current was passed and the experiment ended. The cathode coated with the deposited copper was rinsed first in concentrated nitric acid and then in water; this served as a preparation for the quantitative determination of the copper obtained from the vitreous by means of electrolysis.

\section{Results of Investigations}

Altogether eleven experimental attempts at the electrolytic (anodic) dissolution of copper splinters were carried out. The results of these experiments are presented in Table I.

TABLE I

RESULTS OF ANODIC DISSOLUTION OF COPPER

\begin{tabular}{|c|c|c|c|c|c|c|c|}
\hline \multirow{2}{*}{$\begin{array}{c}\text { Experi- } \\
\text { ment } \\
\text { No. }\end{array}$} & \multirow{2}{*}{$\begin{array}{l}\text { Mass of } \\
\text { Splinter } \\
\text { (mg.) }\end{array}$} & \multirow{2}{*}{ Volts } & \multicolumn{2}{|c|}{$\mathrm{mA}$} & \multirow{2}{*}{$\begin{array}{c}\text { Time } \\
\text { (min.) }\end{array}$} & \multirow{2}{*}{$\begin{array}{l}\text { Current } \\
\text { Efficiency } \\
\text { (per cent) }\end{array}$} & \multirow{2}{*}{ Anode } \\
\hline & & & Range & Mean & & & \\
\hline $\begin{array}{r}1 \\
2 \\
3 \\
4 \\
5 \\
6 \\
7 \\
8 \\
9 \\
.10 \\
11\end{array}$ & $\begin{array}{l}5 \cdot 2 \\
4 \cdot 8 \\
5 \cdot 2 \\
3 \cdot 6 \\
1 \cdot 4 \\
5 \cdot 1 \\
5 \cdot 4 \\
2 \cdot 3 \\
1 \cdot 6 \\
1 \cdot 9 \\
2 \cdot 1\end{array}$ & $\begin{array}{l}4 \cdot 5 \\
4 \cdot 5 \\
3 \cdot 0 \\
3 \cdot 0 \\
3 \cdot 0 \\
4 \cdot 5 \\
4 \cdot 5 \\
4 \cdot 5 \\
4 \cdot 5 \\
4 \cdot 5 \\
4 \cdot 5\end{array}$ & $\begin{array}{r}15-6 \\
15-5 \\
10-4 \\
6-3 \\
6-2 \\
11-5 \\
12-3 \\
13-5 \\
12-4 \\
10-4 \\
7-3\end{array}$ & $\begin{array}{l}9 \\
8 \\
6 \\
4 \cdot 5 \\
4 \\
7 \\
6 \\
8 \\
7 \\
6 \\
5\end{array}$ & $\begin{array}{r}80 \\
80 \\
100 \\
60 \\
20 \\
90 \\
100 \\
30 \\
20 \\
30 \\
35\end{array}$ & $\begin{array}{l}36 \\
38 \\
44 \\
67 \\
88 \\
41 \\
45 \\
48 \\
58 \\
53 \\
61\end{array}$ & $\begin{array}{c}\text { Non-insulated } \\
\text { ", } \\
\text { Insulated } \\
\text {," } \\
\text { ", } \\
\text { Non-insulated } \\
\text {,, } \\
\text {," }\end{array}$ \\
\hline
\end{tabular}

The analysis of current efficiency based on the data collected in Table I shows that its value changes considerably under the influence of several factors. The most important is the mass of the foreign body. This is natural if we consider that only some, especially the chlorine, anions of the vitreous take part in the dissolution of copper. Near the anode their number is comparatively small and decreases steadily as electrolysis continues, so that towards the end of the experiment the function of carrying electric charges is taken over by the hydroxyl ions, which have no influence on the process of dissolution of copper, and only produce gaseous oxygen at the anode.

It was found that when the anode was covered with an insulating coat, only its point being left bare, the efficiency of the dissolving process increased considerably. This is due to the fact that the anions which leave the noninsulated platinum anode above the point of contact take no part in dissolution. It was possible to prove that the dissolution of copper under the influence of a passing electric current went on most actively at the point of contact between the two metals, where the current density is highest. The curves shown in Fig. 1 (opposite) show the evident relation between the mass of the copper splinter and the efficiency of the dissolution current for both the insulated (continuous line) and the non-insulated (dotted line) electrodes. 


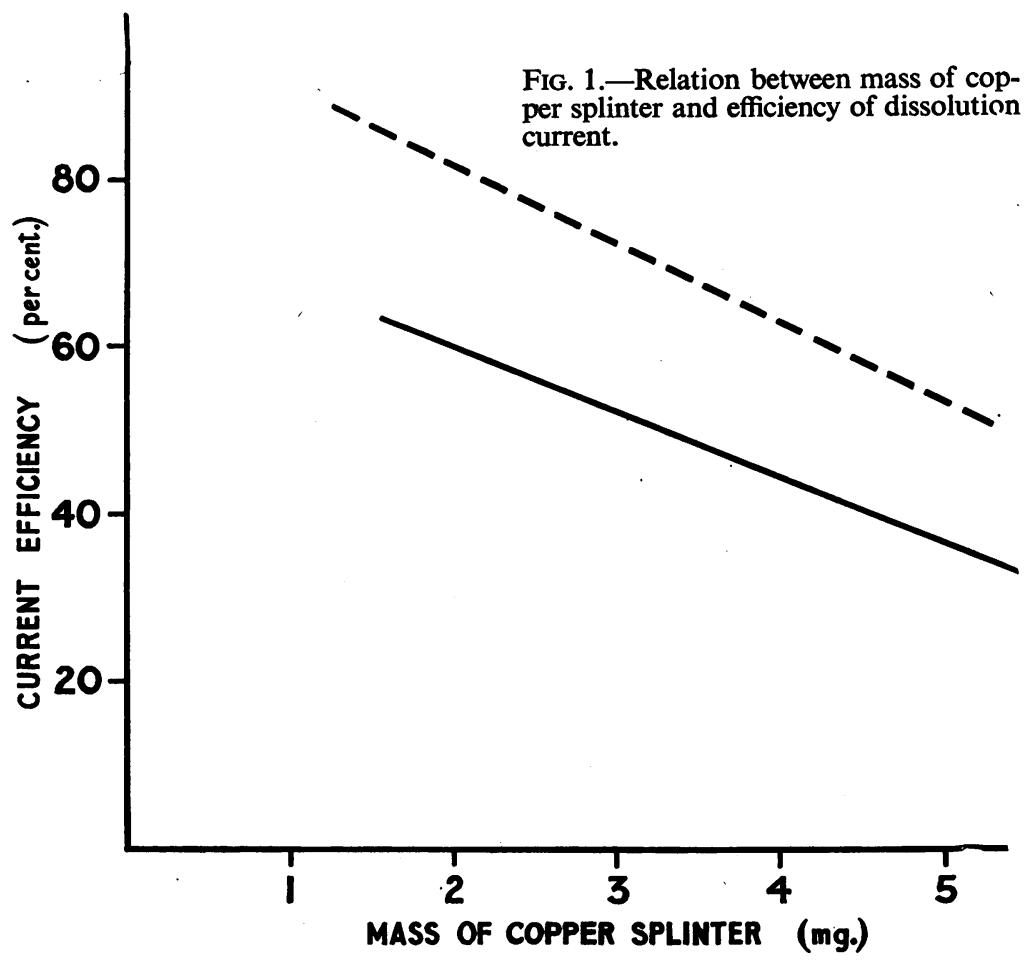

The mechanism of the anodic dissolution of a copper splinter may be explained in the following way. The splinter receives a positive electric charge from the working electrode. This leads to the depolarization of the vitreous anions which at that moment are very close to the anode. If among these depolarized anions there are some which can form chemical compounds with the metal of the anode, in our case with copper, the dissolution of the anode will take place and part of the anodic work of the current will be used for sending cations coming from the dissolved anode into the solution. The ratio of that part of the work of the current used for dissolving the anode to the whole of the work performed by the current, expressed in percentage, is called in this case the dissolution current efficiency. It is expressed by the formula:

$$
\text { Dissolution current efficiency }=\frac{100 C r}{C} \text { per cent. }
$$

where $C r=$ amount of electricity (expressed in coulombs) used for the dissolution of the anode,

$$
\begin{gathered}
C=\text { total amount of electricity (in coulombs) passed through the } \\
\text { electrolyte. }
\end{gathered}
$$

When coulombs are expressed in milliampère-minutes and the part of the work of the current used for dissolving copper is given in milligrammes of dissolved copper, the formula is as follows: 
Dissolution current efficiency $=\frac{100 a}{0.0198 \mathrm{it}}$ per cent. $\quad . \quad$.

where $a=$ amount of copper (in milligrammes) dissolved from the anode in $t$ minutes,

$i=$ mean current intensity (in milliampères) during the experiment,

$t=$ duration of dissolution current (in minutes).

In the second stage of the experiment we attempted to remove copper ions from the vitreous. For this purpose the cathodic precipitation (removal) of the dissolved copper was applied. Deposition of copper on the cathode took place immediately after dissolution on simply reversing the direction of the current. If an insulated electrode had been used in the first stage of the experiment, it was now replaced by a non-insulated one. Copper was deposited along the whole length of the platinum needle submerged in the vitreous and could be

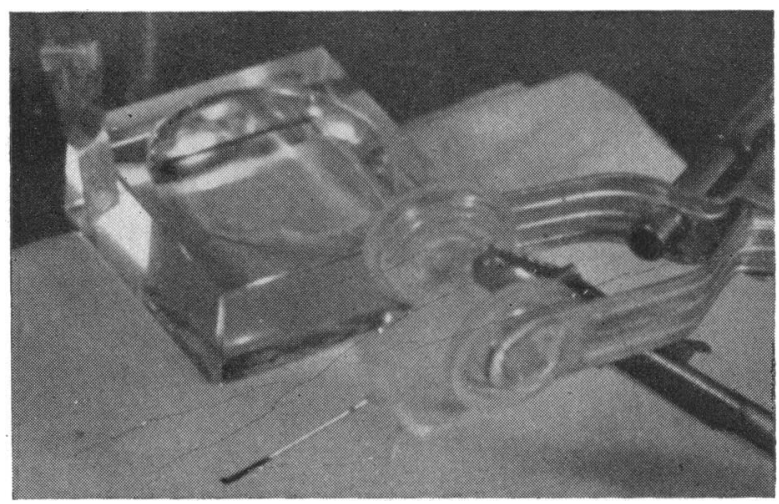
removed together with the electrode (Fig. 2).

FIG. 2.-Copper deposited on platinum needle and removed together with electrode.

The amount of copper deposited on the cathode was determined iodometrically; when a microburette was used, the margin of error in this method was only 5 per cent. The results of cathodic deposition of copper are given in Table II. The efficiency of the deposition current is seen to be much lower

TABLE II

RESULTS OF CATHODIC PRECIPITATION OF COPPER

\begin{tabular}{|c|c|c|c|c|c|c|}
\hline \multirow{2}{*}{$\begin{array}{c}\text { Experi- } \\
\text { ment } \\
\text { No. }\end{array}$} & \multicolumn{2}{|c|}{$\mathrm{mA}$} & \multirow{2}{*}{$\begin{array}{c}\text { Time } \\
(\min .)\end{array}$} & \multirow{2}{*}{$\begin{array}{c}\text { Mass of } \\
\text { Precipitated } \\
\text { Copper (mg.) }\end{array}$} & \multirow{2}{*}{$\begin{array}{l}\text { Current } \\
\text { Efficiency } \\
\text { (percent.) }\end{array}$} & \multirow{2}{*}{$\begin{array}{l}\text { Quantity } \\
\text { of Deposited } \\
\text { Copper } \\
\text { (percent.) }\end{array}$} \\
\hline & Range & Mean & & & & \\
\hline $\begin{array}{r}2 \\
3 \\
4 \\
5 \\
6 \\
7 \\
8 \\
9 \\
10 \\
11\end{array}$ & $\begin{array}{l}60-4 \\
52-5 \\
52-4 \\
48-4 \\
55-5 \\
58-5 \\
52-4 \\
50-4 \\
46-4 \\
46-4\end{array}$ & $\begin{array}{l}15 \\
12 \\
14 \\
16 \\
12 \\
18 \\
15 \\
18 \\
12 \\
12\end{array}$ & $\begin{array}{l}45 \\
45 \\
55 \\
20 \\
50 \\
40 \\
20 \\
20 \\
20 \\
20\end{array}$ & $\begin{array}{l}2.0 \\
2.5 \\
2.0 \\
0.9 \\
2.6 \\
3.3 \\
1.7 \\
1.1 \\
1.4 \\
1.7\end{array}$ & $\begin{array}{l}15 \\
23 \\
13 \\
14 \\
22 \\
26 \\
29 \\
15 \\
29 \\
36\end{array}$ & $\begin{array}{l}42 \\
48 \\
56 \\
66 \\
51 \\
61 \\
76 \\
71 \\
75 \\
79\end{array}$ \\
\hline
\end{tabular}


than that of the dissolution current. The total percentage of copper deposited on the cathode is in inverse proportion to the initial mass of the splinter and, therefore, to the duration of electrolysis. This might suggest that when electrolysis lasts too long, the copper passes into irreversible complex compounds from which it cannot be precipitated electrochemically.

When the copper is dissolved and the current discontinued, the vitreous surrounding the anode presents a complex mixture of various chemical compounds. The dissolved copper passes into the solution first as a chloride; some of the chlorine ions which have lost their electric charge on the working electrode are given off in the form of gaseous chlorine. This active element combines freely with the surrounding proteins, giving various products of chlorination. The atomic oxygen which forms at the anode, especially in the later stage of dissolution, partly takes the free, gaseous form, and partly reacts with the free chlorine giving subchlorous acid, the remainder probably exerting an oxygenating effect on the organic compounds which surround the anode. The copper chloride, which initially passes into the vitreous, may also combine with the proteins to form copper albuminates, or may undergo hydrolysis in the vitreous.

In view of the purpose of our investigations it was particularly important to find out what quantity of copper remains in the vitreous in the form of ions, and what quantity enters into stable complex compounds or assumes an insoluble form, as the metal is only liable to electrolytic precipitation on the cathode in the ion form. In the conditions of our experiment it was possible to remove by means of cathodic deposition up to 79 per cent. of the copper dissolved in the vitreous. The residue of the copper probably passed into a non-ionized form and could not be deposited on the cathode independently of the duration of the electrolytic process.

The results of our investigations show that it is is possible to obtain anodic dissolution of a copper splinter in the isolated vitreous, as well as cathodic deposition of a considerable part of the splinter (up to 79 per cent.), and thus to remove the metal as a thin coat covering the cathode. It would be too much to expect that these experiments might influence the clinical procedure of removing copper foreign bodies, but further investigations, carried out if possible on experimental animals, may assist the practical application of this idea.

\section{Summary}

The anodic dissolution of a copper splinter placed in isolated bovine vitreous was investigated using insulated and non-insulated electrodes. The current efficiency of the process was calculated, and the relation between the current efficiency and the mass of the splinter and the kind of electrode was shown graphically.

In the second part of the experiment the possibility of the cathodic precipitation of the dissolved copper was investigated and the current efficiency of this process was also calculated. 
The results of the investigations show that it is possible to dissolve and precipitate electrochemically up to 79 per cent. of copper particle placed in an isolated bovine vitreous.

\section{REFERENCES}

DuKE-EldER, S. (1954). “Text-book of Ophthalmology", vol. 6, p. 6196. Kimpton, London. ENDT, P. M., and Ten DoessChate, J. (1949). Brit. J. Ophthal., 33, 97.

Habig, J. M., Lumen, A., and Snacken, J. (1951). Bull. Soc. belge Ophtal., No. 98, p. 287. (Cited by Duke-Elder, 1954.)

MelanowsKi, W. H. (1956). Postepy Okulist., 3, 131.

Müller, H. K. (1931). Klin. Mbl. Augenheilk., 86, 453. (Cited by Duke-Elder, 1954.)

Newell, F. W., Cooper, J. A. D., and Farmer, C. J. (1949). Amer. J. Ophthal., 32, No. 6, Pt. II, p. 161. (Cited by Duke-Elder, 1954.)

Wölflina (1946). Cited by Melanowski (1956), p. 136. 